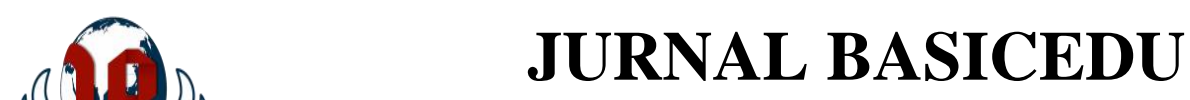

Volume 5 Nomor 3 Tahun 2021 Halaman 1259 - 1270

Research \& Learning in Elementary Education

https://jbasic.org/index.php/basicedu

\title{
Pengembangan Bahan Ajar Matematika SMP Berbasis Kearifan Lokal di Sekolah Menengah Pertama
}

\author{
Rosliana Harahap \\ Tadris Matematika, IAIN Takengon, Indonesia \\ E-mail: r05liana007@gmail.com
}

\begin{abstract}
Abstrak
Penelitian ini bertujuan mendeskripsikan langkah pengembangan bahan ajar matematika SMP berbasis budaya lokal (budaya Gayo) pada semester ganjil, serta mendiskripsikan kualitas hasil perangkat pembelajaran tersebut. Kualitas hasil pengembangan ditentukan berdasarkan kriteria valid dan praktis dan efektif. Penelitian ini merupakan penelitian pengembangan. Tahap-tahap yang dimulai meliputi potensi dan masalah, pengumpulan data, desain produk,validasi desain, revisi desain, uji coba produk, uji coba produk, revisi produk, uji coba pemakaian, revisi produk, produksi masal. Uji coba dilakukan dengan enam tahap meliputi potensi dan masalah, pengumpulan data, desain produk,validasi desain, revisi desain, uji coba produk. Uji coba lapangan (produk) dilakukan di MTS Bustanul Ulum Takengon di kelas VII. Intrumen penelitian yang digunakan lembar validasi perangkat pembelajaran dan angket respon siswa, serta ujicoba hasil belajar siswa. Penelitian ini menghasilkan: Bahan Ajar dinyatakan valid dengan nilai buku guru adalah 0,87; buku siswa adalah 0,80; dengan katagori sangat valid, sehingga dapat digunaka Bahan ajar dinyatakan praktis dengan perolehan nilai rata-rata dari respon siswa $83 \%$ dengan katagori baik. Bahan ajar dinyatakan efektif dengan perolehan nilai rata-rata dari hasil belajar siswa 73,5 dengan 75\% siswa berada di atas KKM.
\end{abstract}

Kata Kunci: bahan ajar, pengembangan, berbasis budaya lokal, matematika.

\begin{abstract}
This study aims to describe the steps in developing mathematics teaching materials for junior high schools based on local culture (Gayo culture) in odd semesters, as well as to describe the quality of the learning tools. The quality of development results is determined based on valid and practical and effective criteria. This research is a development research. The stages that begin include potentials and problems, data collection, product design, design validation, design revision, product testing, product testing, product revision, usage testing, product revision, mass production. The trial was carried out in six stages including potentials and problems, data collection, product design, design validation, design revision, product testing. Field trials (products) were conducted at MTS Bustanul Ulum Takengon in grade VII. The research instrument used validation sheets for learning devices and student response questionnaires, as well as testing student learning outcomes. This study resulted in: teaching materials were declared valid with a teacher book value of 0.87; student book is $0.80 ; ;$ with a very valid category, so that it can be used. Teaching materials are declared practical with the acquisition of an average value of $83 \%$ student response with a good category. Teaching materials were declared effective with the acquisition of an average value of 73.5 student learning outcomes with $75 \%$ of students being above the KKM.
\end{abstract}

Keywords: teaching materials, development, based on local culture, mathematics.

Copyright (c) 2021 Rosliana Harahap

Corresponding author :

Email : r05liana007@gmail.com

DOI : https://doi.org/10.31004/basicedu.v5i3.884

ISSN 2580-3735 (Media Cetak)

ISSN 2580-1147 (Media Online) 

Rosliana Harahap

DOI: https://doi.org/10.31004/basicedu.v5i3.884

\section{PENDAHULUAN}

Matematika adalah ilmu yang mendasar bagi ilmu-ilmu lainnya, matematika memilki peranan yang baik karena mengandung pelanaran yang logis, dan modal untuk penguasaan ilmu dan teknologi. Sehingga matematika di sekolah perlu dikembangkan agar dapat menumbuhkan kecerdasan, keterampilan, kedisiplinan, etika dan moral yang baik dari peserta didik. Salah satu cara untuk mengembangkan matematika di sekolah adalah dengan pengembangkan pendekatan pembelajaran matematika. Pendekatan pembelajaran matematika dapat dimulai dengan pengembangan bahan ajar yaitu buku siswa dan buku guru.

Salah satu sumber belajar di sekolah adalah bahan ajar, sehingga bahan ajar harus sederhana, mudah dipahami siswa dan mengandung pengetahuan yang tinggi. Bahan ajar adalah segala bentuk bahan atau materi yang disusun secara sistematis yang digunakan untuk membantu guru atau instruktur dalam melaksanakan kegiatan belajar mengajar sehingga tercipta lingkungan atau suasana yang memungkinkan siswa untuk belajar. Bahan ajar disebut juga teaching-materia.(Hambali, 2011), sedangkan menurut (Lestari, 2013) bahan ajar harus didisain dengan baik sesuai dengan aturan yang baku, karena bahan ajar digunakan oleh guru dalam menyampaikan materi kepada anak didik. Bahan Ajar yang baik tentunya akan sangat membantu guru menyampaikan materi sehingga peserta didik lebih gampang memahami materi yang disampaikan oleh gurunya.seperti yang dikemukakan oleh (Abdul Majid dan Chaerul Rochman, 2015) dalam menyusun bahan ajar harus memiliki suatu tujuan, ada beberapa tujuan yang harus dipenuhi oleh bahan ajar yaitu . bahan ajar harus dapat membantu siswa dalam mempelajari dan memahami isi dari materi, menyediakan pilihan bagi siswa, membantu guru agar lebih mudah menjelaskan suatu materi, dan yang terakhir bahan ajar harus dapat membuat suasana belajar lebih menarik.

Bahan ajar secara garis besar terdiri atas pengetahuan, keterampilan, dan sikap yang harus dipelajari siswa dalam angka mencapai standar kompetensi yang telah ditentukan. jenis materi fakta adalah nama-nama objek, peristiwa sejarah, lambang, nama tempat, nama orang. Materi konsep adalah pengertian, definisi, ciri khusus, komponen, atau bagian suatu objek. Materi prinsip adalah dalil, rumus, teorema atau hubungan antar konsep yang menggambarkan hubungan sebab akibat. Materi jenis prosedur adalah materi yang berkenaan dengan langkah-langkah secara sistematis atau berurutan dalam mengerjakan suatu tugas. Materi jenis sikap (afektif) adalah materi yang berkenaan dengan sikap atau nilai, misalnya nilai kejujuran, kasih sayang, tolong menolong, semangat dan minat belajar, semangat bekerja. Salah satu bahan ajar adalah buku siswa dan buku guru, buku menjadi bahan ajar paling utama di dalam proses pembelajaran. Ini terbukti hampir diberbagai institusi pendidikan, dari jenjang yang paling dasar hingga yang paling tinggi, pada umumnya menggunakan buku teks pelajaran sebagai bahan ajar utamanya. Hal ini membuktikan pula keberadaan buku teks pelajaran masih merupakan bagian yang tidak terpisahkan dari proses pembelajaran yang berlangsung diberbagai situasi pendidikan. Namun bahan ajar yang berbasis kearifan local masih sangat minim.

Kearifan lokal berasal dari dalam masyarakat sendiri, disebarluaskan secara nonformal, dimiliki secara kolektif oleh masyarakat bersangkutan, dikembangkan diadaptasi, serta tertanam di dalam cara hidup masyarakat sebagai sarana untuk bertahan hidup selama beberapa generasi dan mudah diadaptasi, serta tertanam di dalam cara hidup masyarakat sebagai sarana untuk bertahan hidup (N, 2016). Kearifan lokal adalah kebudayaan tradisional yang dimilki oleh setiap suku atau bangsa. Kearifan local yang berasal dari suku bangsa dapat berupa budaya yang ada di daerah tersebut yang berupakan adaptasi dari kebiasaan masyarakat atau adaptasi dari luar. Selain itu kearifan lokal suku dapat berasal dari nilai-nilai agama, norma ataupun tradisi suatu wilayah (Edy Sedyawati., 2006). Kearifan lokal dapat berupa aturan-aturan tak tertulis yang menjadi pedoman hidup masyarakat suatu wilayah, misalkan aturan pernikahan, setiap daerah memilki aturan yang berbeda dalam pernikahan, sopan santun dan tata kerama dalam bermasyarakat; aturan yang menyangkut hubungan manusia dengan alam, misalnya dilarang mengambil ikan di sungai larangan, selain itu kearifan lokal dapat berupa adat istiadat termasuk tarian, musik, rumah adat, institusi, kata-kata bijak, pepatah 

Rosliana Harahap

DOI: https://doi.org/10.31004/basicedu.v5i3.884

(Fahrudin dan Rahmat, 2012). Nilai-nilai luhur yang ada dalam kearifan lokal (local wisdom) dapat memperkuat jati diri bangsa dan menanamkan kecintaan terhadap bangsa serta negara. Hal itu disebabkan kearifan lokal diambil dari nilai-nilai luhur yang ada di dalam masyarakat itu sendiri. Kearifan lokal merupakan produk budaya masa lalu yang patut secara terus-menerus dijadikan pegangan hidup. Meskipun bernilai lokal tetapi nilai yang terkandung di dalamnya dianggap sangat universal. Menurut (Sartini, 2006) kearifan lokal memiliki beberapa fungsi yaitu sebagai konservasi dan pelestarian sumber daya alam, pengembangan sumber daya manusia, pengembangan kebudayaan dan ilmu pengetahuan, sebagai petuah, kepercayaan, sastra dan pantangan, tatanan sosial misalnya upacara dalam upacara-upacara adat, tuntunan etika dan moral dalam bermasyarakat, dan bermakna politik.

Pembelajaran berbasis kearifan lokal adalah pembelajaran yang memanfaatkan keunggulan-keunggulan yang ada di suatu daerah yang meliputi bidang ekonomi, seni budaya, SDM, bahasa, teknologi informasi dan komunikasi, ekologi, dan lain-lain ke dalam pembelajaran di sekolah yang akhirnya bermanfaat bagi pengembangan kompetensi peserta didik dan dapat dimanfaatkan untuk persaingan global (Trisngati, 2015) Sehingga mata pelajaran matematika sangat sesuai jika dikaitkan dengan nilai- nilai kearifan lokal, karena diharapkan mampu meningkatkan penguasaan konsep dan pemahaman Matematika bagi siswa sekaligus membangun pengetahuan siswa terhadap daerahnya dan membentukan karakter dalam diri siswa.

Salah satu cara mengintegrasi kearifan lokal dalam bahan ajar matematika yaitu dengan mengaitkan materi yang ada dalam matematika dengan aspek-aspek yang ada dalam kearifan local misalnya kekayaan alam yang ada di suatu daerah. Misalkan seorang guru ingin menjelaskan tentang materi himpunan, seorang guru dapat memberikan contoh anggota himpunan yang berasal dari kekayaan alam yang ada di daerah tersebut, contoh lainnya pada materi linear satu variable, guru dapat menjelaskan variable dalam materi persamaan linear satu variable dengan nama tarian yang ada di daerah tersebut. Melalui pembelajarn yang seperti ini maka siswa akan lebih tertarik untuk belajar matematika dan akhirnya kemampuan bermatematika siswa dapat meningkat dan pengetahuan tentang kearifan local yang ada di darahnya juga bertambah.

Hal ini sejalan dengan penelitian terdahulu yang dilakukan oleh (Hasibuan \& Hasibuan, 2020) tentang efektifitas bahan ajar berbasis budaya Mandailing untuk meningkatkan kemampuan komunikasi matematis siswa, adapun hasil penelitian beliau adalah bahwa bahan ajar berbasis budaya Mandailing efektif untuk meningkatkan kemampuan komunikasi matematis siswa. Kemampuan komunikasi yang paling meningkat adalah kemampuan membuat gambar matematis yaitu semua indikator keefektivan bahan ajar telah memenuhi kriteria yang ditetapkan yakni ketuntasan belajar klasikal mencapai 90,467\%, respon siswa positif terhadap bahan ajar, waktu aktivitas siswa berada pada waktu ideal, dan bahan ajar terlaksana dengan sangat baik. Hasil penelitian ini memberikan motivasi dan dukungan kepada guru untuk mengembangkan bahan ajar sendiri. Guru dapat menggunakan bahan ajar berbasis budaya Mandailing sebagai alternatif pembelajaran yang digunakan untuk meningkatkan kemampuan komunikasi matematis siswa. Oleh karena itu guru hasrus mampu mengembangkan bahan ajar yang sesuai dengan karakter siswa. Peran budaya dalam pembelajaran harus dimaksimalkan agar siswa lebih tertarik untuk mengikuti pembelajaran yang akan berakibat kepada kemampuan matematis siswa semakin baik.

Dan penelitian lainnya yang dilakukan oleh (Dazrullisa, 2018) menunjukkan pembelajaran berbasis kearifan lokal dapat meningkatkan minat siswa, adapun hasil penelitiannya yaitu berdasarkan hasil angket sebanyak 76,16\% siswa berminat mempelajari pembelarajan matematika berbasis kearifan lokal. Selain itu hasil belajar siswa juga berpengaruh, dimana ketuntasan belajar sudah mencapai nilai KKM sebesar 63 dengan ketuntasan belajar klasikal sebesar 82,08\% dan nilai rata-rata kelas sebesar 16,41. Dari keseluruhan 27 siswa, seluruhnya tuntas. Berdasarkan peneltian penelitian terdahulu kearifan local memilki peran yang sangat baik dalam proses pembelajaran matematika, untuk itu perlu dilakukan pengembangan bahan ajar matematika berbasis kearifan local sehingga semakin variasi bahan ajar yang dapat digunakan oleh guru-guru dengan 
1262 Pengembangan Bahan Ajar Matematika SMP Berbasis Kearifan Lokal di Sekolah Menengah Rosliana Harahap

DOI: https://doi.org/10.31004/basicedu.v5i3.884

tujuan tercapainya tujuan dari pendidikan matematika, adapun (Ariyadi, 2012)tujuan dari pendidikan matematika yaitu Tujuan praktis yaitu pengembangan kemampuan siswa untuk menggunakan matematika dalam menyelesaikan masalah yang terkait dengan kehidupan sehari-hari, Tujuan kemasyarakatan yaitu kemampuan siswa untuk berpartisipasi secara aktif dalam hubungan kemasyarakatan, Tujuan profesional mengembangkan kemampuan siswa untuk menghadapi dunia kerja, Tujuan budaya yaitu kemampuan siswa mengembangkan budaya dan menyaring budaya asing yang sesuai dengan kepribadian bangsa.

\section{METODE PENELITIAN}

Jenis penelitian ini adalah penelitian pengembangan yang disebut juga dengan Reasrch \& Development $(R \& D)$ merupakan suatu proses yang dipakai untuk mengembangkan dan memvalidasi produk pendidikan. Produk yang dikembangkan dan dihasilkan dalam penelitian ini yaitu buku guru, buku siswa dan angket. Prosedur penelitian dan pengembangan pada penelitian ini menggunakan prosedur penelitian dan pengembangan menurut (Sugiono, 2017) sebagai berikut:

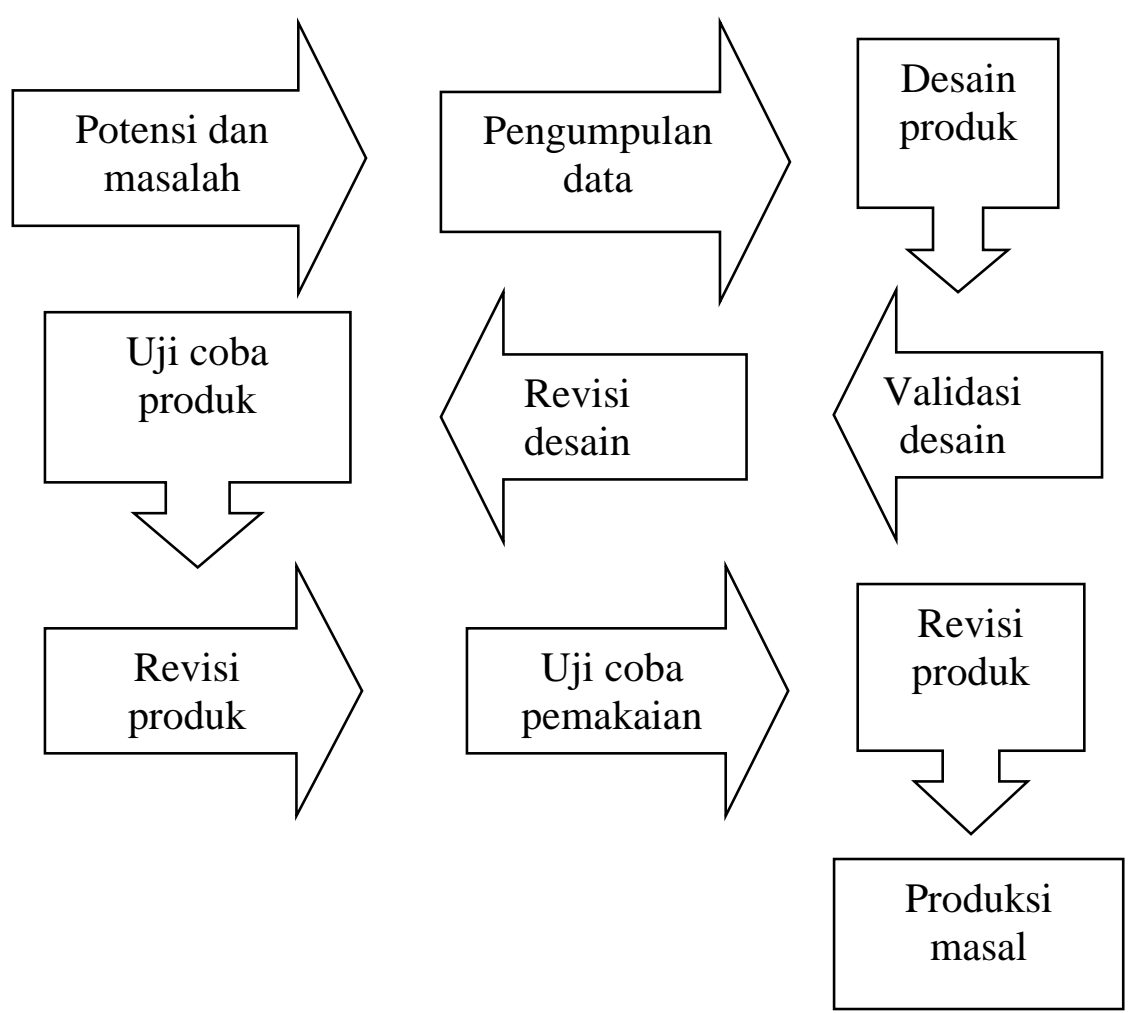

Gambar 1 : Langkah-Langkah PenggunaanMetode Research and Development

Adapun penjelasan dari gambar di atas sebagai berikut:

1. Potensi dan Permasalahan

Potensi adalah segala sesuatu yang apabila didayagunakan akan memiliki nilai tambah. Sedangkan masalah adalah penyimpangan antara yang diharapkan dengan yang terjadi.

2. Pengumpulan Data

Pengumpulan data dilakukan di MTS Bustanul Ulum Takengon. Pengumpulan data dilakukan dengan menggunakan teknik wawancara dan observasi. Hasil dari observasi diharapkan bisa menemukan 
1263 Pengembangan Bahan Ajar Matematika SMP Berbasis Kearifan Lokal di Sekolah Menengah Rosliana Harahap

DOI: https://doi.org/10.31004/basicedu.v5i3.884

permasalahan dalam proses pembelajaran dan potensi yang terdapat dalam di sekolahan selama proses pembelajaran.

\section{Desain Produk}

Tahap ini dimulai dengan menyusun desain produk berupa bahan ajar berbasis kearifan local (suku Gayo). Pembuatan bahan ajar terlebih dahulu dilakukan dengan mengecek silabus semester ganjil dan dilanjutkan dengan menyusun buku dan membuat buku dengan cara per sub-BAB.

4. Uji Ahli

Uji Ahli dilakukan oleh pakar atau tenaga ahli dengan menggunakan lembar instrumen penilaian. Dalam penelitian ini ada tiga pakar. Pakar atau ahli bahan ajar ditujukan untuk memvalidasi produk yang meliputi validasikelayakan kontruksi, validasi bahasa, dan validasi isi. Bahan ajar dikatakan valid jika menurut validator setiap komponen yang ada pada produk masuk kekategori valid atau sangat valid.

\section{Revisi Produk}

Setelah desain produk divalidasi oleh para pakar atau tenaga ahli, maka akan dapat diketahui kelemahan dan kekurangannya. Setelah diketahui kelemahan dan kekurangan maka peneliti akan memperbaiki dan menyempurnakan produk tersebut.

\section{Uji Terbatas}

Uji coba produk terbatas dilakukan setelah bahan ajar yang dikembangkan selesai direvisi dan dinyatakan valid oleh pakar. Kemudian selanjutnya diimplementasikan pada peserta didik dengan jumlah terbatas. Implementasi skala kecil ini bertujuan untuk mengetahui kesiapan produk sebelum diuji cobakan pada skala besar. Subjek Uji Coba dalam penelitian ini adalah siswa kelas VII MTS Bustanul Ulum Takengon.

Setelah melakukan uji coba produk berupa bahan ajar maka diperoleh data kualitatif. Data yang akan diperoleh nantinya berupa kategori nilai kualitas bahan ajar berdasarkan penilaian kualitas bahan ajar oleh dua validator, y. Kemudian data kualitatif ini nanti dapat dikuantitatifkan dengan memberi skor dan rangking. Data berupa skor didapatkan dari penilaian kualitas bahan ajar berupa nilai yang dinilai oleh validator. Kategori kualitas bahan ajar oleh ahli yaitu dengan rentangan nilai 1-4. Data kualitatif juga didapatkan dari respon siswa sebagi pengguna bahan ajar untuk mengetahui kepraktisan bahan ajar, selain itu data kualitatif juga didapatkan dari masukan dan saran yang diberikan oleh validator atau penilai dan masukan dari pengguna bahan ajar yaitu siswa dan guru.

Analisis data yang dilakukan untuk mendapatkan bahan ajar berbasis kearifan lokal yang valid, praktis dan efektif yaitu dengan menggunakan rumus Gregory (Pradnya parmita, 2017). Penilaian hasil dari hasil uji ahli isi dihitung menggunakan rumus Gregory. Para pakar yang dipercaya menilai instrumen melakukan penilaian intrumen perbutir, pengelompokan skala sesuai atau tidak sesuai, Hasil para pakar ditabulasi silang, misalnya untuk dua penilai seperti pada tabel di bawah ini: 
1264 Pengembangan Bahan Ajar Matematika SMP Berbasis Kearifan Lokal di Sekolah Menengah Rosliana Harahap

DOI: https://doi.org/10.31004/basicedu.v5i3.884

Tabel 1. Hasil penilaian para pakar

\begin{tabular}{|l|l|l|l|}
\cline { 3 - 4 } \multicolumn{2}{c|}{} & \multicolumn{2}{|c|}{ Validator 1 } \\
\cline { 3 - 5 } & \multirow{2}{*}{$\begin{array}{l}\text { Kurang relevan } \\
(1-2)\end{array}$} & $\begin{array}{l}\text { Kurang relevan } \\
(3-4)\end{array}$ \\
\hline \multirow{3}{*}{ Validator 2 } & Kurang relevan (1-2) & (A) & (B) \\
\cline { 3 - 5 } & Kurang relevan (1-2) & (C) & (D) \\
\hline
\end{tabular}

Perhitungan validasi isi dengan rumus

Validasi isi $=\frac{D}{A+B+C+D}$

Kerangan

A $\quad=$ sel yang menunjukan ketidak setujuan kedua penilai

$\mathrm{B}$ dan $\mathrm{C} \quad=$ sel yang menunjukan perbedaan pandangan antara penilai

$\mathrm{D} \quad=$ sel yang menunjukan kesetujuan antara kedua penilai

Untuk melihat tingkat pencapaian kriteria validitas isi dapat dilihat pada tabel 2

Tabel 2. Tingkat Pencapaian Kriteria Validitas Isi

\begin{tabular}{|c|c|}
\hline Koefesien Validitas & Tingkat Validitas \\
\hline $0,91-1,00$ & Sangat Tinggi \\
\hline $0,71-0,90$ & Tinggi \\
\hline $0,41-0,70$ & Cukup \\
\hline $0,21-0,40$ & Rendah \\
\hline $0,00-0,20$ & Sangat Rendah \\
\hline
\end{tabular}

Dalam (Adi Sudibjo, 2013) untuk Analisis kepraktisan perangkat pembelajaran diperoleh dari angket respon siswa. Respon siswa bias positif bias pula negatif, untuk mengnalisis kepraktisan perangkat pembelajaran dapat dilakukan dengan cara membuat table penskoran, nilai maksimal dari respon siswa perbutir pertanyaan adalah 4 dan nilai minimal respon siswa adalah satu, untuk lebih jelas akan ditampilkan pada table.3.

a. Tabulasi data skor hasil angket respon siswa dengan mengelompokan butir-butir pertanyaan sesuai dengan aspek-aspek yang diamati.

Tabel 3. Penskoran Angket Respon Siswa

\begin{tabular}{|c|c|c|}
\hline \multirow{2}{*}{ Pemilihan jawaban } & \multicolumn{2}{|c|}{ Skor pernyataan } \\
\cline { 2 - 3 } & Positif & Negative \\
\hline Selalu (SL) & 4 & 1 \\
\hline Sering (S) & 3 & 2 \\
\hline Pernah (P) & 2 & 3 \\
\hline Tidak pernah (TP) & 1 & 4 \\
\hline
\end{tabular}



Rosliana Harahap

DOI: https://doi.org/10.31004/basicedu.v5i3.884

b. Mengitung rata-rata skor aspek dengan menggunakan rumus

Persentase respon $=\frac{\text { jumlah } \text { skor }}{\text { jumlah skor maksimal }} \times 100$

Hasil analisis angket respon interpretasi skor adalah sebagai berikut:

Tabel 4. interpretasi skor

\begin{tabular}{|c|c|}
\hline Persentase & Kriteria \\
\hline $0 \%-20 \%$ & Sangat kurang \\
\hline $21 \%-40 \%$ & Kurang \\
\hline $41 \%-60 \%$ & Cukup \\
\hline $61 \%-80 \%$ & Baik/layak \\
\hline $81 \%-100 \%$ & Sangat baik/sangat layak \\
\hline
\end{tabular}

c. Analisis keefektifan produk bahan ajar

Menurut Arikunto, keefektifan adalah taraf tercapainya tujuan yang ditentukan, Adapun kriteria keefektifan sebagai yaitu ketuntasan belajar sekurang-kurangnya $75 \%$ dari jumlah siswa telah memperoleh nilai $\leq 70$ dalam peningkatan hasil belajar.

\section{HASIL DAN PEMBAHASAN}

Jenis penelitian ini adalah Reserch and Development $(R \& D)$ dengan produk yang dikembangkan berupa Buku Guru dan Buku Siswa pada pelajaran matematika kelas VII di semester ganjil. Model pengembangan yang digunakan dalam penelitian ini adalah model pengembangan 4D dengan tahap define (pendefinisian), design (perancangan) develop (pengembangan) dan disseminate (penyebaran), namun karena keterbatasan peneliti maka penelitian ini hanya sampai tahap develop (pengembangan) saja.

Proses pengembangan bahan ajar menggunakan tujuh tahap prosedur pengembangan model sugiono yang telah dimodifikasi enam tahap yaitu Potensi dan Permasalahan, Pengumpulan Data, Desain Produk, Uji Ahli, Revisi Produk, Uji Terbatas, Revisi. Berdasarkan penelitian pengembangan yang dilakukan, diperoleh hasil sebagai berikut:

Potensi dan Permasalahan . Potensi dan permasalahan bahan ajar khususnya matematika diperoleh pada kelas VII semester ganjil di MTs Bustanul Ulum Takengon, adapun permasalahan yang peneliti temukan yaitu pada buku siswa belum ada mengkaitkan budaya local. Pada tahap kedua peneliti mencari potensi dengan wawancara. Wawancara dilakukan dengan guru matematika yang ada di MTs Bustanul Ulum Takengon. Wawancara bertujuan untuk memperoleh informasi mengenai pembelajaran matematika, buku guru dan buku siswa serta pengetahuan siswa tentang budaya lokal. Dari wawancara dapat disimpulkan memenuhi analisis kebutuhan. Setelah mendapatkan data, selanjutnya dilakukan desain produk, langkah pertama adalah menentukan SK dan KD, kemudian menentukan indicator. Langkah selanjutnya adalah mencari sumber belajar berupa materi dan gambar-gambar yang dapat menunjang buku guru, buku siswa. Setelah produk berupa buku guru dan buku siswa selesai dibuat, dilakukan validasi produk dengan memberikan lembar penilaian yang berskala kan 1-4, yang akan di isi oleh validator. Terdapat 2 validator produk, yaitu seorang dosen pendidikan matematika dan guru matematika SMP. Adapun hasil dari validator satu dan dua sebagai berikut: 
DOI: https://doi.org/10.31004/basicedu.v5i3.884

Tabel 5. Rekapitulasi Pengujian Buku Guru

\begin{tabular}{|c|c|c|c|}
\hline \multicolumn{2}{|c|}{ Validaror I } & \multicolumn{2}{c|}{ Validator II } \\
\hline $\begin{array}{c}\text { Kurang Relevan } \\
\text { (Skor 1-2) }\end{array}$ & $\begin{array}{c}\text { Sangat Relevan } \\
(\mathbf{3 - 4})\end{array}$ & $\begin{array}{c}\text { Kurang Relevan } \\
\text { (Skor 1-2) }\end{array}$ & $\begin{array}{c}\text { Sangat Relevan ( } \\
\mathbf{3 - 4})\end{array}$ \\
& & & \\
\hline & $1,2,3,4,5,6,7,8$, & & $1,2,3,4,5,6,7,8$, \\
& $10,12,13,14,15$, & & $10,11,12,13,14$ \\
\hline
\end{tabular}

Hasil dari dua orang validator (pakar) dimasukan kedalam tabulasi silang $(2 \times 2)$ yang terdiri dari empat kolom yang ditunjukan pada tabel 6 berikut

Tabel 6. Tabulasi Silang (2x2) Hasil Penilaian Kedua Validator

\begin{tabular}{|c|c|c|c|}
\hline & & \multicolumn{2}{|c|}{ Validator 1} \\
\hline & & $\begin{array}{l}\text { Kurang } \\
\text { relevan (1-2) }\end{array}$ & Kurang relevan (3-4) \\
\hline \multirow{2}{*}{ Validator 2} & $\begin{array}{l}\text { Kurang relevan } \\
(1-2)\end{array}$ & $\begin{array}{l}\text { A } \\
\text { (0) }\end{array}$ & $\begin{array}{l}\mathrm{B} \\
(2)\end{array}$ \\
\hline & $\begin{array}{l}\text { Kurang relevan } \\
(1-2)\end{array}$ & $\begin{array}{l}\mathrm{C} \\
\text { (0) }\end{array}$ & $\begin{array}{c}\mathrm{D} \\
(\mathbf{1 3})\end{array}$ \\
\hline
\end{tabular}

$$
\begin{aligned}
\text { Validasi isi } & =\frac{D}{A+B+C+D} \\
& =\frac{13}{0+2+0+13} \\
& =\frac{13}{15} \\
& =0,87
\end{aligned}
$$

Dengan demikian dari hasil perhitungan Gregory diperoleh validasi isi 0,87. Kesimpulannya Buku Guru yang divalidasi memiliki kriteria validasi isi kategori tinggi. Ditinjau dari kelayakan kontruksi, bahasa dan isi, sehingga buku guru dapat digunakan pada tahap selanjutnya.

Tabel 7. Rekapitulasi Pengujian Buku Siswa

\begin{tabular}{|c|c|c|c|}
\hline \multicolumn{2}{|c|}{ Validaror I } & \multicolumn{2}{c|}{ Validator II } \\
\hline $\begin{array}{c}\text { Kurang Relevan } \\
\text { (Skor 1-2) }\end{array}$ & Sangat Relevan (3-4) & $\begin{array}{c}\text { Kurang Relevan } \\
\text { (Skor 1-2) }\end{array}$ & Sangat Relevan (3-4) \\
\hline $\mathbf{9}$ & $\begin{array}{c}1,2,3,4,5,6,7,8,10, \\
11,12,13,14,15\end{array}$ & 9,11 & $1,2,3,4,5,6,7,8,10$, \\
& & & $12,13,14,15$ \\
\hline
\end{tabular}


1267 Pengembangan Bahan Ajar Matematika SMP Berbasis Kearifan Lokal di Sekolah Menengah Rosliana Harahap

DOI: https://doi.org/10.31004/basicedu.v5i3.884

Hasil dari dua orang validator (pakar) dimasukan kedalam tabulasi silang $(2 \times 2)$ yang terdiri dari empat kolom yang ditunjukan pada tabel 4.5 berikut:

Tabel 8. Tabulasi Silang (2x2) Hasil Penilaian Kedua Validator

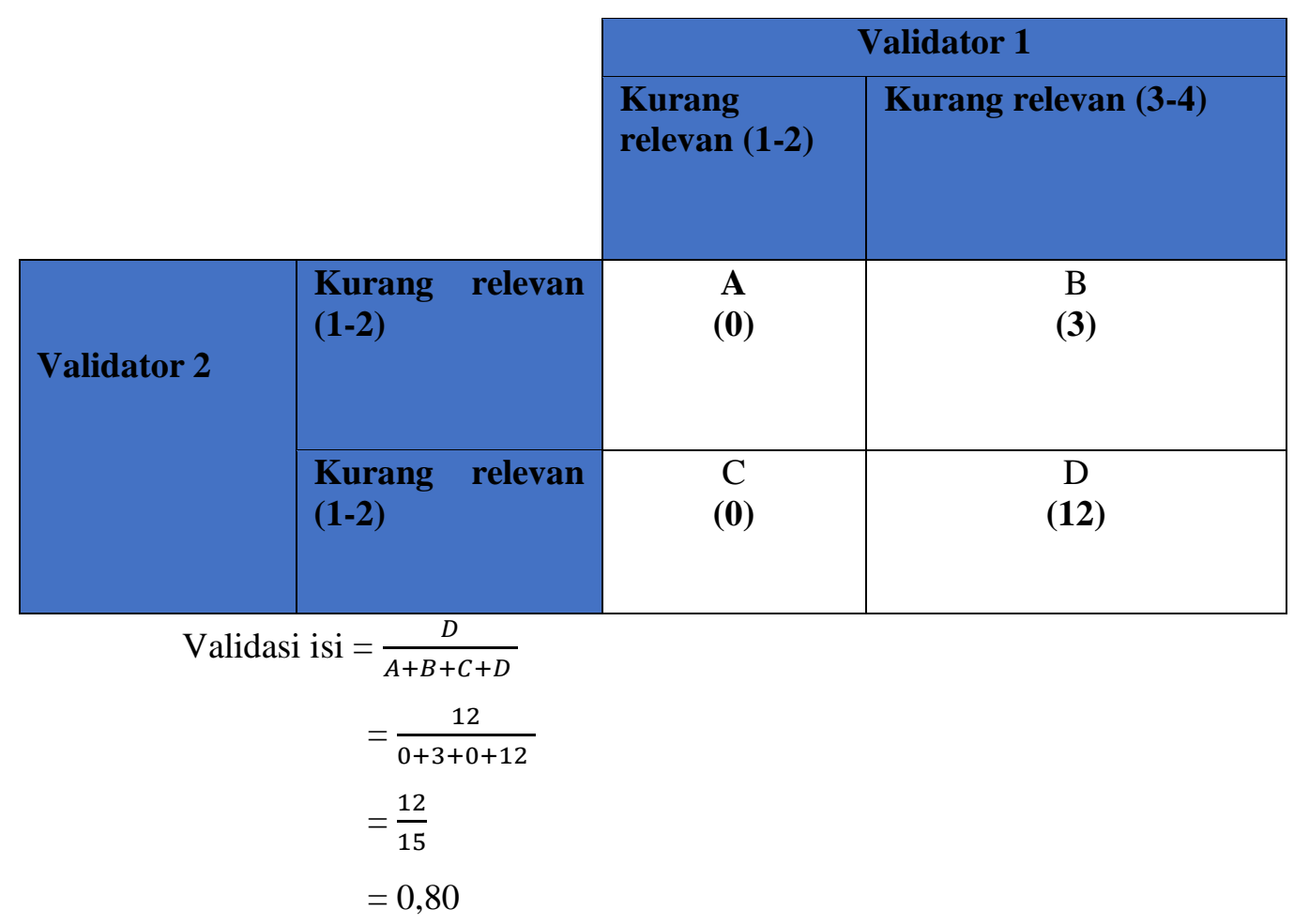

Dengan demikian dari hasil perhitungan Gregory diperoleh validasi isi 0,80. Kesimpulannya Buku Siswa yang divalidasi memiliki kriteria validasi isi tinggi. Ditinjau dari kelayakan kontruksi, bahasa dan isi, sehingga buku siswa dapat digunakan pada tahap selanjutnya.

Setelah desain produk divalidasi oleh validator, maka produk berupa buku guru dan buku siswa dilakukan revisi sesuai dengan saran dari kedua validator. Uji coba produk terbatas dilakukan setelah bahan ajar yang dikembangkan selesai direvisi dan dinyatakan valid oleh validator. Kemudian selanjutnya diimplementasikan pada peserta didik dengan jumlah terbatas. Implementasi skala kecil ini bertujuan untuk mengetahui kesiapan produk sebelum diuji cobakan pada skala besar. Dalam penelitian ini yang menjadi subjek uji terbatas adalah peserta didik kelas VII-1 MTs Bustanul Ulum Takengon. Kepraktisan perangkat dilihat berdasarkan hasil angket yang diisi oleh siswa, selain itu dilihat juga berdasarkan keterlaksanaan perangkat pembelajaran. Hasil uji coba produk dilakukan dengan menganalisis kepraktisan perangkat pembelajaran berdasarkan hasil analisis angket respon siswa digunakan untuk melihat tanggapan siswa dalam mengembangkan perangkat pembelajaran. Adapun hasil angket respon siswa sebesar 83\%, dalam kategori baik. Dan Kefektifan produk dalam kategori tuntas, karena rata-rata tes hasil belajar siswa mencapai 73,5, dengan lebih dari $75 \%$ mendapat nilai di atas 70 .

Pengembangan produk bahan ajar ini melalui enam tahap yaitu Potensi dan Permasalahan, Pengumpulan Data, Desain Produk, Uji Ahli, Revisi Produk, Uji Terbatas, Revisi. Ke enam tahapan telah dilakukan dengan baik, sehingga produk bahan ajar ini dapat dipakai sebagai penunjang pembelajaran. Produk bahan ajar berbasis budaya lokal, yaitu pada budaya suku gayo dilakukan agar siswa dalam belajar matematika dapat tertarik, dan mengubah matematika yang awalnya jauh dari kehidupan siswa menjadi dekat dengan kehidupan sehari-hari siswa. Produk bahan ajar ini memenuhi syarat validasi isi, validasi isi dinilai 
1268 Pengembangan Bahan Ajar Matematika SMP Berbasis Kearifan Lokal di Sekolah Menengah Rosliana Harahap

DOI: https://doi.org/10.31004/basicedu.v5i3.884

oleh validator yang paham terhadap matematika dan ilmu pendidikan matematika. Adapun nilai validasi produk dalam kategori tinggi.

Produk bahan ajar sebelum diujicoba dilakukan validasi oleh pakar, dan direvisi sesuai saran pakar/validator, salah satunya seperti pada gambar dibawah ini
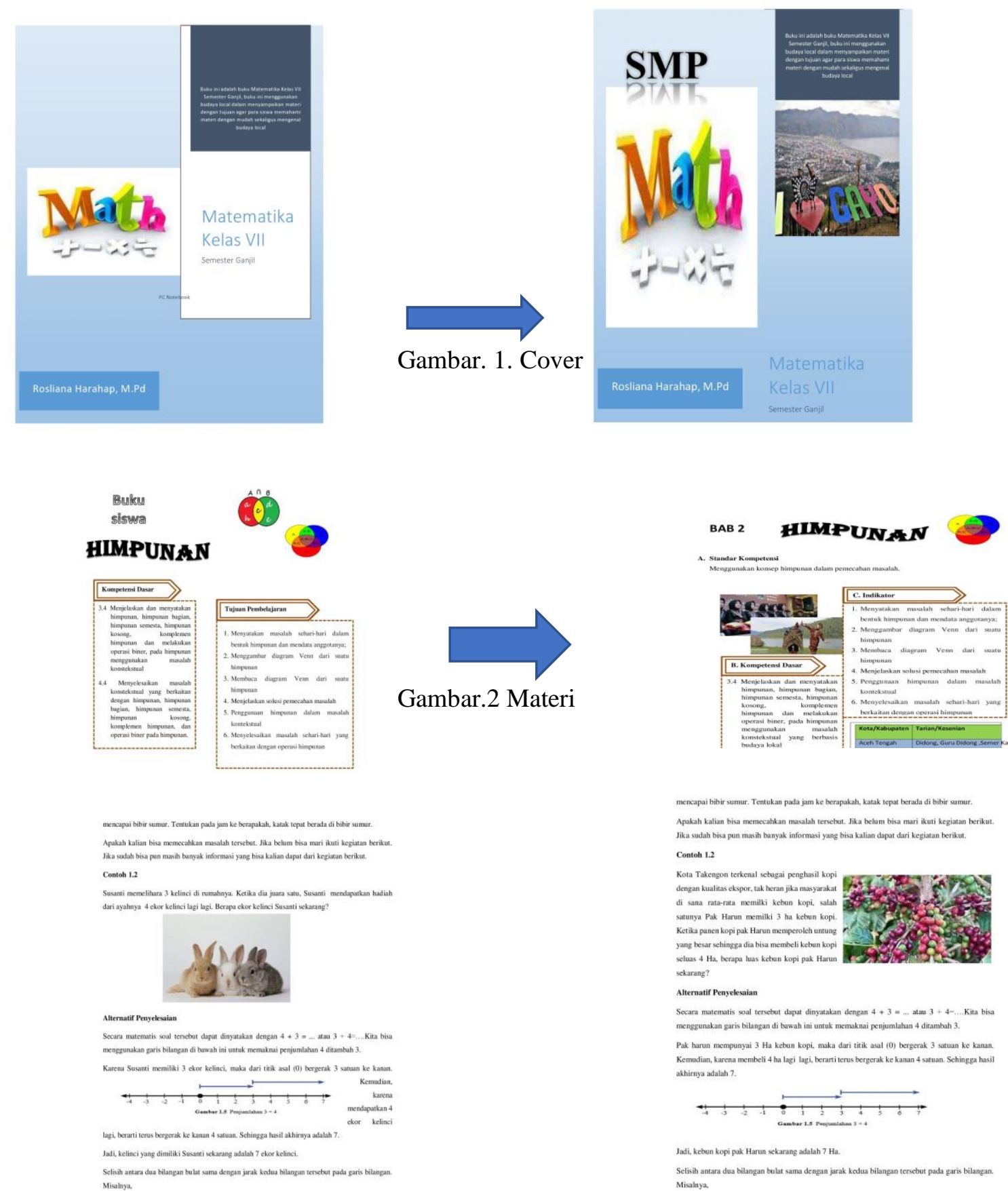

Bahan ajar direvisi sesuai dengan saran validator, seperti pada gambar. 1, cover buku dibuat menggunakan karakteristik suatu wilayah, gambar.2 merupakan materi yang ada di buku, yaitu materi himpunan, pada saat menjabarkan kosep materi validator memeberi saran agar mengkaitkan dengan situasi di wilayah tersebut. Pada gambar.3 yaitu contoh soal, dalam contoh soal permasalahan dibuat menggunakan potensi alam yang ada di daerah tersebut, semua itu bertujuan agar siswa lebih tertarik dalam mengeksplor mengetahuan tentang matematika dan daerahnya. 

Rosliana Harahap

DOI: https://doi.org/10.31004/basicedu.v5i3.884

Setelah produk bahan ajar berbasis budaya lokal dikatakan valid, selanjutnya produk di ujicobakan untuk melihat kepraktisan dan keefektifan produk. Kepraktisan produk diperoleh dari respon siswa terhadap produk, siswa diberikan angket. Ada 10 butir pertanyaan angket yang berhubungan dengan keterkaitan bahan ajar dengan budaya local dan ketertarikan siswa dalam belajar matematika dengann menggunakan bahan ajar berbasis budaya local. Dari respon siswa diperoleh respon positif terhadap produk bahan ajar berbasis budaya lokal.

Selanjutnya dilakukan tes hasil belajar siswa, tes hasil belajar siswa bertujuan untuk memperoleh data nilai siswa, nilai siswa dihitung untuk melihat kefektifan produk. Nilai rata-rata siswa 73,5, nilai tersebut nilai 70 dan terdapat lebih $75 \%$ siswa yang memperoleh nilai tersebut sehingga produk bahan ajar berbasis budaya local dapat dikatakan efektif. Karena produk bahan ajar berbasis budaya lokal memenuhi kriteria valid, praktis dan efektif, maka bahan ajar ini dapat digunakan sebagai penunjang proses pembelajaran di kelas. Produk bahan ajar berbasis budaya lokal sangat baik diterapkan dalam proses pemebalajaran karena selain siswa memperoleh pengetahuan matematika siswa juga dapat mengenal budaya daerahnya sendiri. Seperti yang dikemukakan oleh Trisngati mata pelajaran matematika sangat sesuai jika dikaitkan dengan nilai- nilai kearifan lokal, karena diharapkan mampu meningkatkan penguasaan konsep dan pemahaman Matematika bagi siswa sekaligus membangun pengetahuan siswa terhadap daerahnya dan membentukan karakter dalam diri siswa.

\section{KESIMPULAN}

Adapun kesimpulan dari penelitian ini adalah: Penelitian pengembangan ini menghasilkan bahan ajar berupa Buku guru dan Buku siswa, untuk mata pelajaran matematika kelas VII semester ganjil. Bahan Ajar dinyatakan valid dengan nilai buku guru adalah 0,87 ; buku siswa adalah 0,$80 ;$; dengan katagori sangat valid, sehingga dapat digunakan. Bahan ajar dinyatakan praktis dengan perolehan nilai rata-rata dari respon siswa 83\% dengan katagori baik. Bahan ajar dinyatakan efektif dengan perolehan nilai rata-rata dari hasil belajar siswa 73,5 dengan $75 \%$ siswa berada di atas KKM

\section{DAFTAR PUSTAKA}

Abdul Majid dan Chaerul Rochman. (2015). Pendekatan Ilmiah Dalam Implementasi Kurikulum 2013. Remaja Rosdakarya.

Adi Sudibjo, W. (2013). penggunaan media pembelajaran fisika dengan E-Learning Edmono Blog Education pada materi alat optic untuk meningkatkan respon motivasi dan hasil siswa di SMP Negeri 4 Surabaya. Innovasi Pendidikan Fisika, 2(3).

Ariyadi, W. (2012). Pendidikan Matematika Realistik, Suatu Alternatif. Pendekatan Pembelajaran Matematika. Graha Ilmu.

Dazrullisa. (2018). PENGARUH PEMBELAJARAN MATEMATIKA BERBASIS KEARIFAN LOKAL TERHADAP MINAT BELAJAR SISWA. Genta Mulia, 9(2), 141-149.

Edy Sedyawati. (2006). Budaya Indonesia (Kajian Arkeologi, Seni, dan Sejarah). PT Raja Grafindo Persada.

Fahrudin dan Rahmat, M. (2012). Internalisasi pendidikan keimanan berbasis tassawuf sebagai upaya membentuk karakter manusia arifun billah di SMA Pomasda Tanjung Anom Nganjuk Jawa Timur. Integrias, 1(1), 122-140.

Hambali. (2011). Strategi Belajar Mengejar. CV Pustaka Setia.

Hasibuan, S. A., \& Hasibuan, S. S. (2020). EFEKTIVITAS BAHAN AJAR MATEMATIKA BERBASIS BUDAYA MANDAILING DALAM MENINGKATKAN KEMAMPUAN KOMUNIKASI MATEMATIS SISWA. MAJU (Jurnal Ilmiah Pendidikan Matematika), 7(2), 141-152. 
1270 Pengembangan Bahan Ajar Matematika SMP Berbasis Kearifan Lokal di Sekolah Menengah Rosliana Harahap

DOI: https://doi.org/10.31004/basicedu.v5i3.884

Lestari, I. (2013). Pengembangan Bahan Ajar Berbasis Kompetensi. Akademia Permata.

N, P. (2016). Peranan Pendidikan Karakter Berorientasi Kearifan Lokal dalam Pengembangan Kemampuan Pemecahan Masalah. Proceeding Seminar Nasional MIPA.

Pradnya parmita, N. P. (2017). Pengembangan E-Modul Pembelajaran Admistrasi Server Kelas XI TI Bali Global Singaraja. Jurnal Pendidikan Teknik Imformaatika, 6.

Sartini. (2006). Menggali Kearifan Lokal Nusantara (1st ed.). UGM.

Sugiono. (2017). Metode Penelitian Kuantitatif, Kualitatif, dan R\&D. AlFabet.

Trisngati, U. (2015). Proses Berpikir Reflektif Mahasiswa dalam Pemecahan Masalah pada Materi Himpunan ditinjau dari Gaya Kognitif Berdasarkan Langkah Polya. Pendidikan Matematika, 8(2), 127-136. 